PROOF $\square 30342 \square$ IJPS $\square 167 \square 6 \square 2006 \square$ DER $\square$ CHECKED $\square$ 09/15/06

Int. J. Plant Sci. 167(6):000-000. 2006.

(c) 2006 by The University of Chicago. All rights reserved.

1058-5893/2006/16706-00XX\$15.00

\title{
FLORAL STRUCTURE, ANTHER DEVELOPMENT, AND POLLEN DISPERSAL OF HALOPHYTUM AMEGHINOI (HALOPHYTACEAE)
}

\author{
Raúl Pozner ${ }^{1}$ and Andrea Cocucci \\ Instituto de Botánica Darwinion (National Council for Scientific and Technological Research [CONICET]), Casilla de Correo 22, \\ B1642HYD San Isidro, Buenos Aires, Argentina; and Instituto Multidisciplinario de Biología Vegetal (CONICET), \\ Universidad Nacional de Córdoba, Casilla de Correo 495, 5000 Córdoba, Argentina
}

\begin{abstract}
A developmental and anatomical study of the staminate flowers of Halophytum ameghinoi showed decussate tepal estivation; residual growth of the receptacle after stamen inception; monocotyledonous and basic types of anther wall development; secretory, binucleate tapetal cells; tetrahedral tetrads; and binucleate pollen grains. A vacuolate stage in the archesporial cells, the structure of endothecial thickenings, and a mechanism of anther dehiscence by connective contraction are new autapomorphies for this family. Anemophily is confirmed (Plantago-type syndrome), and field studies of pollen release showed a subtle mechanism involving rigid anther wall structure, versatile anther insertion, and abaxial subterminal pores. In air currents, while anthers flutter with pores directed upwind, pollen is extracted presumably by a cavitation effect of the hooded anther tip. In a phylogenetic context, anemophily of Halophytum is of isolated occurrence within Caryophyllales, and uniovulate ovaries in sister clades probably represent a prerequisite for evolution of anemophily.
\end{abstract}

Keywords: anther development, Halophytum, morphology, pollen dispersal, staminate flower.

\section{Introduction}

The monotypic family Halophytaceae was established by Soriano (1946, 1984; see also Eckardt 1976). Its single species, Halophytum ameghinoi (Speg.) Speg., is endemic of semidesertic areas of western and southwestern Argentina. Soriano's article (1946) is the major source of information about floral structure, which becomes particularly deformed in dried herbarium specimens. Although the pollen morphology of Halophytum has been studied in detail (Skvarla and Nowicke 1976; Nowicke and Skvarla 1979), nothing is known concerning its pollen and anther development (Davis 1966; Johri et al. 1992). Similarly, pollination is not yet recorded but is presumed to be anemophilous (Bittrich 1993a).

During the past $30 \mathrm{yr}$, the Caryophyllales have been the focus of intense systematic research (Cuénoud et al. 2002 and literature therein). One family, the Halophytaceae, has usually left a void of information in many structural characters because of its restricted distribution and reduced availability of plant material. Subsequent to the progress made by molecular cladistic studies on the Caryophyllales (Cuénoud et al. 2002 and literature therein), particularly including systematic relationships of Halophytaceae, the evolution of morphological characters within this order can be analyzed on molecular trees. In this context, structural information of poorly known, controversial families such as Halophytaceae becomes necessary.

This study focuses mainly on pollen and anther wall development, the phenology of the anthesis, and the pollination

${ }^{1}$ Author for correspondence; e-mail rpozner@darwin.edu.ar. Manuscript received April 2005; revised manuscript received June 2006. mechanism, with additional data on floral structure. Results are discussed within the context of published information about systematic relationships of Halophytaceae.

\section{Material and Methods}

\section{Floral Structure, Pollen, and Anther Development}

Material from four populations of Halophytum ameghinoi (table 1) was fixed in FAA and Allen Bouin III (Ruzin 1999) by applying partial vacuum in the field. Staminate inflorescences were rinsed in tap water, dehydrated using a graded ethanol series, clarified with xylene, and embedded in Histoplast (Ruzin 1999). Serial sections 4-8 $\mu \mathrm{m}$ thick were stained with PAS-hematoxylin-fast green and mounted with Eukitt. Photographs of histological sections were taken with a Zeiss Standard 18 microscope and Kodak T-MAX film. Details of fixed anthers were photographed with a Zeiss stereomicroscope. Initial development of cellulose endothecial thickenings was observed with polarizing microscopy. Mature endothecial thickenings and their distribution over the anther wall in paradermal view were studied with differential interference contrast (Nomarski type). Characterization of the early sporangial development follows Pozner (2001). Davis (1966) was followed to classify the pattern of anther wall development.

For SEM studies, fixed staminate inflorescences were dehydrated with a graded ethanol series plus two final changes of $100 \%$ acetone. This material was critical-point dried, with $\mathrm{CO}_{2}$ as transitional fluid, and coated with gold palladium using a BAL-TEC SCD 050. Samples were observed and photographed using a Zeiss 940-A scanning electron microscope from the Electron Microscopy Service of Darwinion Institute. 


\section{Table 1}

Sampled Populations of Halophytum ameghinoi, Voucher Specimens, and Depository Herbarium

\begin{tabular}{ll}
\hline Population locality & Reference specimen \\
\hline $\begin{array}{l}\text { Argentina, San Juan; Departamento de Ullún: Lomas de las Tapias, cruce del camino } \\
\text { de Bahía de las Tablas, lat. } 31^{\circ} 27^{\prime} \text { S, long. } 68^{\circ} 38^{\prime} \mathrm{W}, 768 \mathrm{~m} \text {, April 5, 1998 }\end{array}$ & Pozner 154 (SI), Pozner 155 (SI), Pozner 156 (SI) \\
$\begin{array}{l}\text { Argentina, San Juan; Departamento de Ullún: Lomas de las Tapias entre el cruce a } \\
\text { Bahía de las Tablas y el camino a las confiterías del dique, April 5, 1998 }\end{array}$ & Pozner 157a (SI), Pozner 157b (SI), Pozner 157c (SI) \\
$\begin{array}{l}\text { Argentina, San Juan; Departamento de Valle Fértil: Parque Provincial Ischigualasto, } \\
\text { detrás de la casa de recepción al parque, April 6, 1998 }\end{array}$ & Pozner 158 (SI), Pozner 159 (SI) \\
$\begin{array}{l}\text { Argentina, La Rioja; Departamento de General Lavalle: ruta entre Pagancillo y Villa } \\
\text { Unión, frente a un altar, lat. } 29^{\circ} 29^{\prime} \text { S, long. } 68^{\circ} 09^{\prime} \mathrm{W}, \text { April 7, } 1998\end{array}$ & Pozner 160 (SI) \\
\hline
\end{tabular}

Note. Herbarium abbreviations are according to Holmgren et al. (1990).

\section{Pollination Mechanism}

Pollen stickiness was studied by testing for the presence of pollenkitt and the ability of pollen to maintain itself attached to a smooth surface. The presence of pollenkitt was tested for by staining fresh pollen with Sudan IV stain. If present, lipidic droplets on the pollen grains should stain red, and these droplets should also attach to a microscope slide. Adhesive ability was tested by pouring pollen from fresh flowers onto a microscope slide in a circular area $7 \mathrm{~mm}$ in diameter, the cleanliness of which was verified under the microscope. Pollen on the slide was immediately counted without mounting, with $\times 100$ magnification. The pollen sampled was then gently blown, and the amount of remaining pollen on the slide was counted. It was expected that all pollen would be blown away.

The mechanism of pollen issue was studied from a film taken in the field from fresh flowers with a Leica M420 stereomicroscope equipped with a Sony video camera. Freshly opened and older flowers were subjected to local wind and to air currents from different directions produced by a fan placed at a distance of 15 or $30 \mathrm{~cm}$. The population and locality for these studies were the same as for voucher collection Pozner 160. Ca. 12 daylight hours were dedicated to observing the arrival of pollinators to staminate and carpellate flowers.

\section{Results}

\section{Floral Structure}

Cross sections of floral buds show the 4-merous perianth arranged in two outer and two inner tepals. Although the perianth has a valvate estivation at the base (fig. $1 B$ ), tepals become decussate toward the apex (fig. 1C). The outer tepals have flat vernation at the base (fig. $1 B$ ) and are plicate at the distal end (fig. 1C). The inner tepals have flat vernation all along their extension (fig. $1 B, 1 C$ ) and are smaller than the outer ones. A residual growth in the center of the receptacle (apical floral meristem) can be observed during the early developmental stages (fig. 1A). Stamens are oriented centrifugally (fig. $1 B$ ), with lateral to introrse dehiscence toward the apex. Anthers are versatile, with the filament inserted in their upper one-fourth to one-fifth (fig. 1D, 1G). Their abaxial androsporangia are longer than the adaxial ones and slightly recurved (fig. $1 D, 1 E$ ). The stomium is a lateral, longitudinal line that bends toward the adaxial side in the recurved apex of the thecae (fig. $1 D, 1 E$ ).

\section{Androsporogenesis and Androgametogenesis}

Each anther is tetrasporangiate (fig. $1 B$ ). During the early androsporangial development, meristematic features are evident in the hypodermal initials and also in some inner cells (fig. 2A). The archesporial differentiation is expressed only in the first derivatives of the hypodermal initials (fig. 2C). Archesporial cells divide mitotically and undergo a stage of vacuolization (fig. 2D), after which they acquire their typically denser cytoplasm and are able to divide mitotically again (fig. $2 E$ ). The pattern of anther wall development combines both the monocotyledonous (fig. $2 B, 2 C$ ) and basic types. In some cases, a second parietal cell layer derived from the tapetum can be observed. Between prophase I and vacuolated onecelled pollen grain stages, tapetal cells become two-nucleate, and intermediate parietal layers degenerate (fig. 2H). Meiotic cytokinesis is simultaneous, producing tetrahedral tetrads (fig. 2F). After release and hydration, androspores develop as two-celled pollen grains, with dense starch content in the vegetative cell (fig. $2 G$ ). Epidermal cells degrade by the time of differentiation of the endothecium (fig. $3 G$ ), whose cells develop different sorts of thickenings according to their position. Those endothecium cells within the first three to five layers along the lateral slit do not develop any thickenings at all (fig. 3I). These cells have hyaline, thin walls and form a very thin, flexible rim. Those endothecial cells next to the connective and up to one-half of the perimeter of the anther wall develop a continuous, frame-shaped thickening in the anticlinal walls, with a single usually elliptical or ring-shaped thickening in their external periclinal wall (fig. 3J). The remaining endothecium cells in between the rim of the longitudinal slit and the proximal connectival area and the endothecium cells of pore valves develop frame-shaped thickenings in the anticlinal walls, with scalariform or reticulate thickenings in their external periclinal wall (fig. $3 H, 3 I$ ). At anthesis, only the endothecium forms the anther wall.

Having this particular structure, the endothecium cannot produce any movement in the anther wall. However, pore valves do open because the halves of each theca turn outward (fig. $3 A-3 D$ ), connecting both androsporangia in a single chamber with a subpical, adaxial pore and a lateral slit. Transverse sections of anthers before and during anthesis show changes in the distance between thecae and constant 

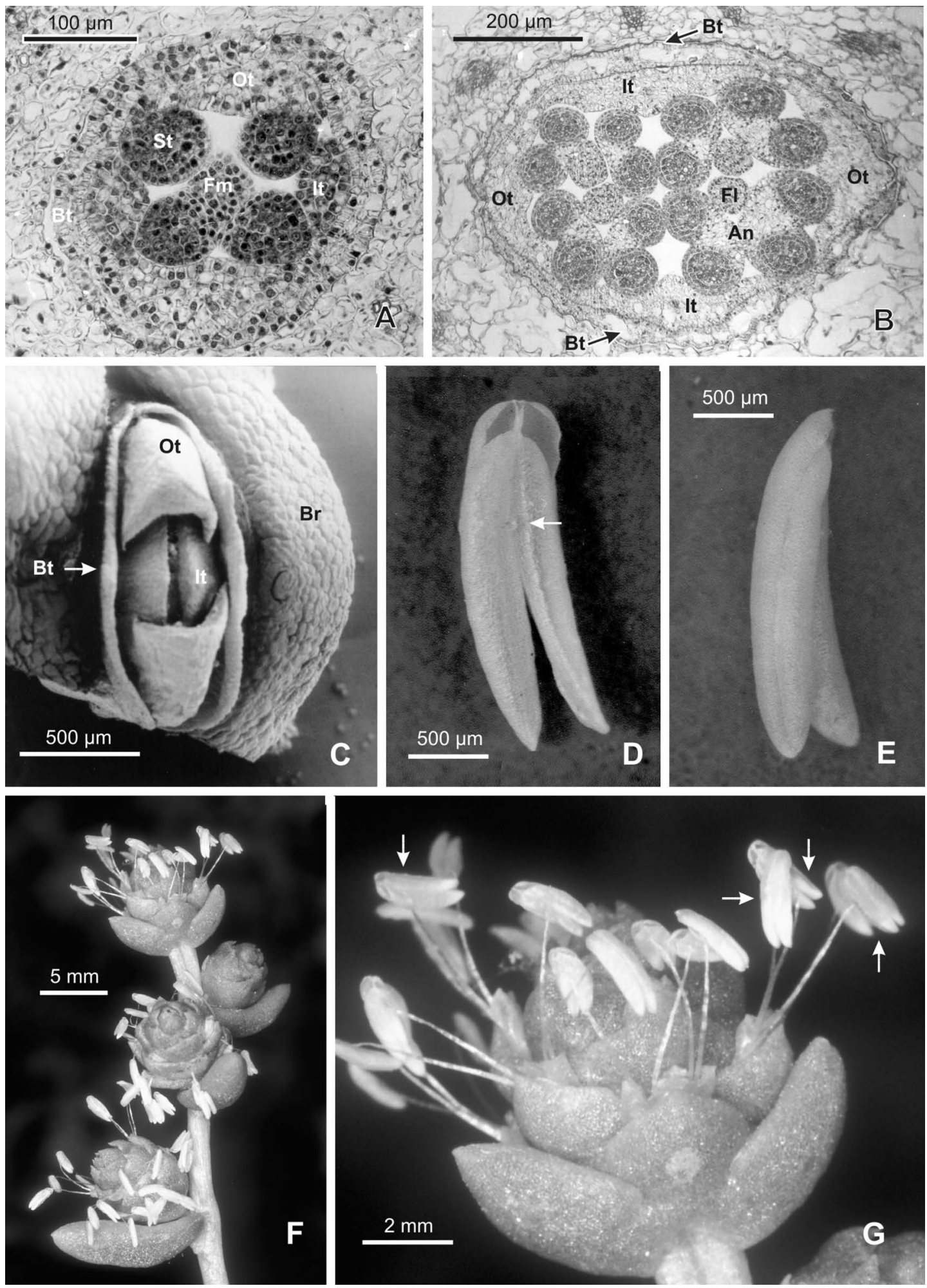

Fig. 1 Halophytum ameghinoi. A, Cross section of a staminate floral primordium, showing the four stamen primordia and residual growth of the apical floral meristem. $B$, Cross section of a floral bud near its base; note the valvate estivation of tepals. C, Early anthesis (SEM), showing the decussate estivation of tepals at their distal portion. $D, E$, Dehiscent anther, showing pores, filament insertion (arrow), and lateral slit. $D$, Adaxial view. E, Lateral view. F, Detail of some staminate spikes during pollen dispersal. $G$, Detail of the most distal spike shown in $F$; note tilted, empty anthers (vertical arrows), with little pollen remaining at the basal end of each theca, and a half-filled anther (horizontal arrow), with the typical vertical position while at rest in still air. $A n=$ anther; $B r=$ bract; $B t=$ bracteole; $F i=$ filament; $F m=$ floral apical meristem; $I t=$ inner tepal; $\mathrm{O} t=$ outer tepal; $S t=$ stamen. 

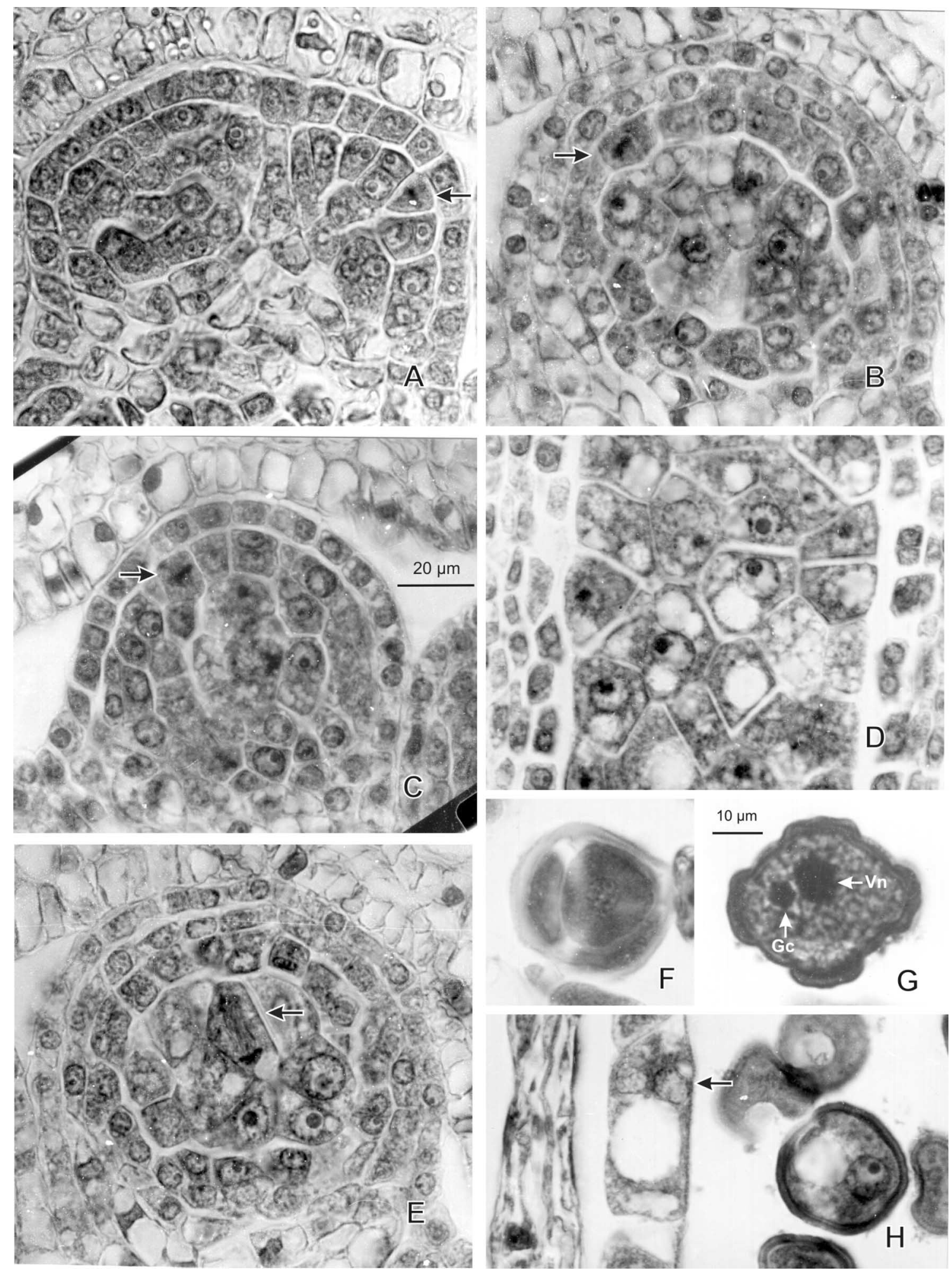

Fig. 2 Halophytum ameghinoi, anther and pollen development. A, Young anther primordium (cross section), showing the first divisions of the subepidermal initial cells (arrow). $B$, Later stage than $C$, showing a mitotic division in the secondary parietal layer (arrow) to originate a tapetum cell and an intermediate layer cell. $C$, Intermediate stage between $A$ and $B$, showing a mitotic division in the primary parietal layer (arrow). $D$, Vacuolated stage of the archesporial cells (longitudinal section). E, Stage similar to $B$, showing a mitotic division of an archesporial cell. $F$, Tetrad. $G$, Section of a two-celled pollen grain (anthesis); note the vegetative nucleus and generative cell. $H$, Detail of one-celled, vacuolated pollen grain and two-nucleate tapetal cell (arrow). $G c=$ generative cell; $V n=$ vegetative nucleus. The scale in $G$ corresponds to that in $F$, as does the scale in $C$ to that in $A, B, D$, and $E$. 


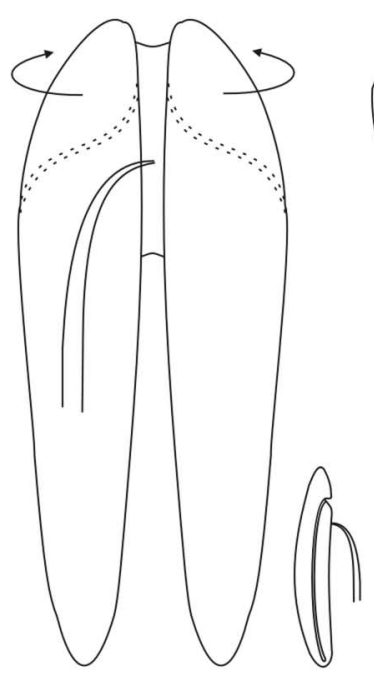

A

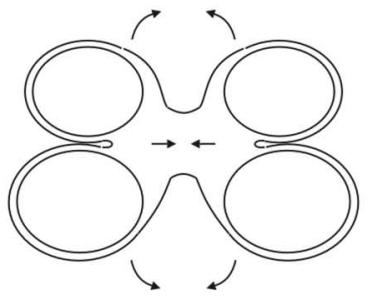

C

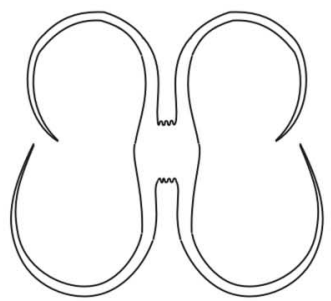

D
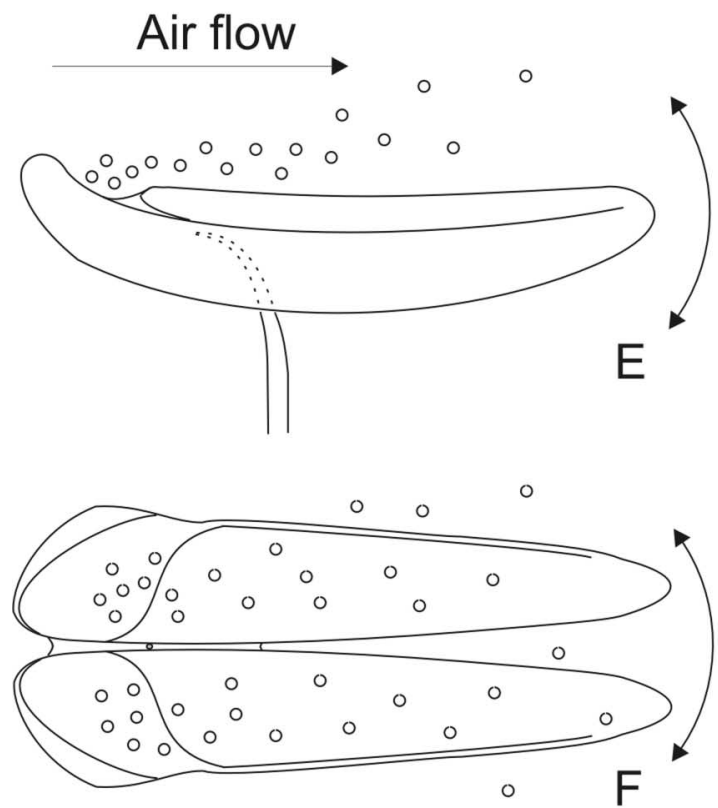
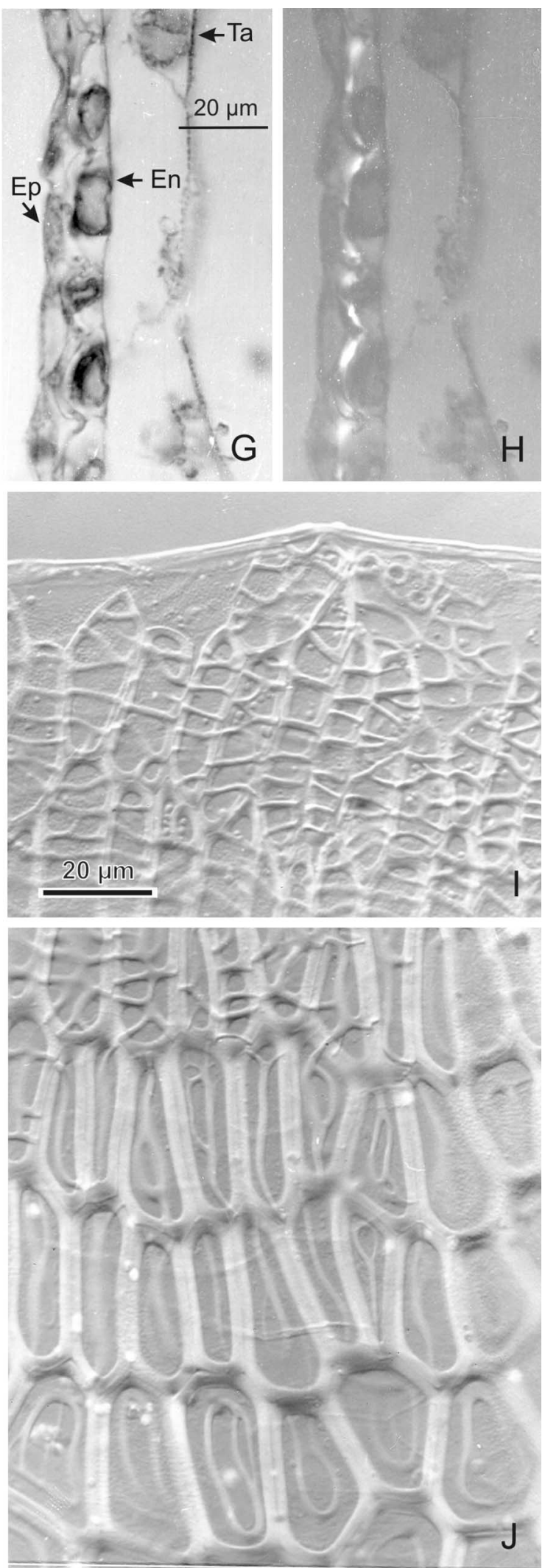

Fig. 3 Halophytum ameghinoi, mechanism of pollen release and structure of endothecium. A, B, Adaxial side and lateral view (smaller drawing) of a mature anther. $A$, Before dehiscence, showing the still unshrunk connective and the adaxial turn of the lateral stomium (dotted lines) at the level of the filament insertion. Arrows indicate the movement produced during the dehiscence of the anther. $B$, Postdehiscence, with lateral 
width and length of the anther wall. This fact suggests that the contraction of the connective and not the enthotecium produces the dehiscence of the anther (fig. $3 A-3 D$ ).

\section{Mechanism of Pollen Release}

Anthers begin to be exposed from the apex from the bud stage, when the perianth opens at noon. Tepals separate from each other by the straightening of their tips, but these do not recurve, so anthers remain initially surrounded by the perianth. Anthers become fully exposed and exserted from the perianth by a remarkable lengthening of the filaments. Though slender, filaments remain turgid during anthesis and radiate straight from the inflorescence with a vertical inclination of about $45^{\circ}$ (fig. $1 F, 1 G$ ). Only the filament tip is flexible, allowing the anthers to move freely. Because anthers are inserted at about their apical one-fourth to one-fifth (fig. 1D, $1 G$ ), they are hanging in a vertical position while at rest (fig. $1 G$; fig. $3 A, 3 B$ ). After releasing its pollen load, the anther's resting position is tilted (fig. $1 G$ ).

When air is still, pollen fills the anthers to the rim of the pores and can be seen through the translucent and very thin anther walls. Pollen is not shed if anthers remain untouched, but it easily moves out of the anthers if they are manually shaken or even gently blown.

Under light wind, part of the pollen is blown out from the anthers if the anthers are open and still fastened by the perianth. When completely exposed, anthers move on their flexible insertion at the slightest air current tilting parallel to the wind direction, always facing the wind with the apex (fig. $3 E, 3 F)$. Under constant wind, anthers flutter sideways in a seesaw fashion but maintain their wind-facing direction (fig. $3 E, 3 F)$. Occasionally, apical pores do not open, and, though lateral slits do open, pollen is not released.

The emptying and depletion of the anthers exposed to air currents could be followed through the translucent anther walls (fig. 1G). The rapid anther movements did not allow visual perception of the process of pollen flowing out of the anthers through the pores. However, it can be interpreted that pollen reaches the apical anther sector by the fluttering movements and that it can exit through the hooded anther apex. Although the anther tips face the wind, wind cannot enter directly through the pores, which, if occurring, would hinder pollen exit through the pores. Because the pores are
Table 2

Number and Percentage of Pollen Grains on a Coverslip before and after a Blowing Test

\begin{tabular}{lcc}
\hline Parameter & Before & After \\
\hline No. pollen grains & 239 & 6 \\
Percentage & 100 & 2.5 \\
Replicate median & 22 & 0 \\
Replicate mean & 23.9 & 0.6 \\
SD & 5.2 & 1.0 \\
\hline
\end{tabular}

Note. Totals of 10 replicates, median, mean, and standard deviation (SD) of replicates are given. A Wilcoxon test for the difference between median number of pollen grains per replicate before and after blowing gave $W=155$ and $P<0.0001$.

subapical in position, the concave apex of the anther actually faces the wind, sheltering the pores. This structure makes sense if considered aerodynamically. A space of low pressure would be generated in the pore region below the apical convex part, thus helping to extract the pollen from the thecae (fig. 3E). No animals were observed approaching the flowers.

\section{Pollenkitt and Pollen Stickiness}

Pollen does not have lipidic droplets detectable with Sudan IV on the surface and does not deposit them on the slides. However, the whole sporoderm stains faintly and uniformly with Sudan IV. The pollen-blowing tests show that almost all of the pollen is blown away; only $2.5 \%$ remained on the slide (table 2).

\section{Discussion}

Halophytum ameghinoi was originally included within the Aizoaceae (sub. Tetragonia; Spegazzini 1899) and then within the Chenopodiaceae (as Halophytum; Spegazzini 1902). Soriano (1946) established this monotypic genus as a new independent family with uncertain, inconclusive systematic relationships among the families of Caryophyllales. Except for Gibson (1978), who supported the original relationship with the Aizoaceae based on secondary growth, subsequent authors during the twentieth century supported two different systematic relationships for the Halophytaceae. Some authors kept the relationship with Chenopodiaceae,

slits and subapical, hooded pores. The lateral views show the lateral portion of the stomium, the convex abaxial side, the flat adaxial side, and the abaxial pollen sacs apically surpassing the adaxial ones. $C, D$, Cross sections of an anther (adaxial side upward). C, Before dehiscence, showing the gap in between the thecae and the still unshrunken connective (arrows within the connective area indicate the directions along which the connective retracts, producing the dehiscence of the anther; the outer arrows show how the anther wall turns during dehiscence; see also $A$ ). $D$, After dehiscence, the connective has shrunken, turning the halves of the anther wall outward and opening the pores (see also $B$ ). E, $F$, Lateral and adaxial view of an anther during pollen release. As the wind blows laterally, the anther aligns to the flow so that its apex faces the wind. Presumably, the negative pressure produced by the air flowing around the hooded pores, combined with shaking (curved arrows), extracts pollen from the anther. The narrow lateral slits allow the air to enter the anther during the process of pollen extraction. $G, H$, Detail of the anther wall (cross section) at the stage when the epidermis and tapetum begin to collapse and degrade and endothecium cells initiate their differentiation. $G$, With normal illumination (bright field). $H$, With a polarizing microscope, showing the birefringent cellulosic thickenings on the periclinal outer wall in the endothecial cells. $I, J$, Paradermal view of the endothecium (Nomarski differential interference contrast). I, Stomium rim without thickenings (top) and cells of the median portion (bottom), with a frame-shaped thickening on the anticlinal wall and scalariform to reticulate thickenings on the outer periclinal wall. $J$, Area closer to the connective, showing the transition from the framed-scalariform endothecial cells (top) to cells with thicker anticlinal walls and a single usually elliptical or ring-shaped thickening on the anticlinal wall (bottom). The scale in $G$ corresponds to that in $H$, as does the scale in $I$ to that in $J$. 
based on general morphology (Hutchinson 1959; Takhtajan 1959; Cronquist 1981) and exine morphology (Skvarla and Nowicke 1976). Some others related Halophytum to the Basellaceae-Phytolaccaceae, based on pollen morphology (Erdtman 1972; Bittrich 1993a) and P-type sieve-tube plastids (Hunziker et al. 1974), and to the Basellaceae and/or Portulacaceae, based on stomatogenesis (Di Fulvio 1975), floral morphology (Takhtajan 1969, 1997), and chromosome number (Hunziker et al. 2000). Recent molecular phylogenies of the Caryophyllales support a sister group relationship of Halophytum with Basellaceae (Savolainen et al. 2000) or Portulacaceae (Cuénoud et al. 2002), always within the succulent clade Cactaceae-Portulacaceae-Basellaceae-Didieraceae.

Anther and pollen development are quite uniform within the Caryophyllales (cf. Johri et al. 1992), and characteristics of these processes in Halophytum do not improve or reinforce the already-known relationships of Halophytaceae with its allied families. However, the vacuolated stage of archesporial cells, the endothecial structure, and the anther opening mechanism by connective contraction can be considered as new structural autapomorphies of Halophytaceae. Endothecium and anther structure are closely related to the functional particular mechanism of anemophilous pollen dispersal rather than systematic relationships.

Exine structure neither clarifies nor reinforces phylogenetic relationships among the families of Caryophyllales in the broad sense or even in the particular case of Halophytaceae. The general shape of the Halophytum pollen grain (subcuboid with one pore on each of the six faces) also appears in Pseudoplantago (Amaranthaceae; Eliasson 1988). The punctate-spinulose exine is the most frequent ornamentation within Caryophyllales (Skvarla and Nowicke 1976; Nowicke and Skvarla 1979). Cactaceae, Caryphyllaceae, Nyctaginaceae, and Phytolaccaceae include pantoporate pollen and other pollen types, while Chenopodiaceae and Amaranthaceae have uniform pantoporate pollen grains. Considering the latest molecular phylogeny of Caryophyllales (Cuénoud et al. 2002), it may be concluded that some palynological features of Halophytum arose at least twice during Caryophyllales phylogeny. Although some ultrastructural characters of the exine may support inclusion of Halophytum in the succulent clade Cactaceae + Portulacaceae + Halophytaceae + Basellaceae +

Q1 Didiereaceae (Nowicke 1996; sub. Portulacineae clade), other palynological characters of Halophytum, such as the lack of pollenkitt and reduced sculpturing and aperture size, are adaptations to wind pollination rather than synapomorphies shared with its closest relatives.

Halophytum ameghinoi exhibits many characters attributed to wind pollination in many anemophilous plants (Faegri and van der Pijl 1979; Linder 1998). These include dioecy, flowers (anthers) well exposed to air currents, a nonshowy and much reduced perianth, uniovulate ovaries, a lack of nectaries, dry pollen, and poricidal anthers. Poricidal anthers are less common in wind-pollinated plants but are present, for example, in many Poaceae and in Cannabis (Knuth 1899). From the functional point of view, the type of anemophily found in Halophytum is equivalent to Plantago because of the versatile anthers exposed on turgid and divergent filaments.

Whether these features evolved in Halophytum as an adaptation to wind pollination or are prerequisites to wind pollination (exaptation) is still an open question. Based on the cladistic study of the Caryophyllales by Cuénoud et al. (2002), it can be settled here that animal pollination is dominant in the higher core Caryophyllales (Nyctaginaceae, Sarcobataceae, Phytolaccaceae, Aizoaceae, Gisekiaceae, Barbeuiaceae, Molluginaceae, Cactaceae, Portulacaceae, Halophytaceae, Basellaceae, and Didieraceae; sensu Cuénoud et al. 2002), most families having bisexual flowers with a showy perianth and nectaries. Transitions to anemophily are apparently of isolated occurrence within some families of this higher core. It has been suggested to occur in a few mesembranthemoid Aizoaceae (Bittrich 1987) and Molluginaceae (Adamson 1955) and is also probable in Pisonia and related genera in the Nyctaginaceae (Pisonieae) according to flower structure (Bittrich and Kühn 1993). Considering that transition to anemophily also took place in the succulent clade Didieraceae-BasellaceaeHalophytaceae-Portulacaceae-Cactaceae, and with Portulacaceae (Claytonia, Portulacaria: Cuénoud et al. 2002) and Basellaceae (Basella: Savolainen et al. 2000; Basella, Anredera: Cuénoud et al. 2002) being the closest sister groups of Halophytum, probable exaptations are the presence of uniovulate ovaries (a widespread trait in Caryophyllales; see Bittrich 1993b) and dioecy if we also consider Didieraceae (see Kubitzki 1993) as the next-closest sister group. Based on the same cladistic analyses (Savolainen et al. 2000; Cuénoud et al. 2002), innovations of Halophytum are a reduced perianth, lack of nectary, poricidal anthers with a hooded cap, and reduction of the endothecium. These can be considered adaptations to anemophily that contribute to the subtle mechanism of pollen dispersal. Precisely because of the specialized anemophily of Halophytum, the study of staminate flower structure, pollen development, and dispersal mode did not reveal new synapomorphies with its closest taxa Basellaceae and Portulacaceae but rather synapomorphies at the order level or new autapomorphies for this monotypic family.

\section{Acknowledgments}

We thank Tito Márques (from San Juan) for helping to locate the plants, Kerstin Mackie (from Victoria) for her kind assistance in the field, and the National Council for Scientific and Technological Research for financial support (PEI 0188/97).

\section{Literature Cited}

Adamson RS 1955 The South African species of Aizoaceae. I. Adenogramma and Polpoda. J S Afr Bot 21:83-95.

Bittrich V 1987 Untersuchungen zu Merkmalsbestand, Gliederung und Abgrenzungen der Unterfamilie Mesembryanthemoideae (Mesembryanthemaceae Fenzl.). Mitt Inst Allg Bot Hambg 23B:491-507. - 1993a Halophytaceae. Pages 320-321 in K Kubitzki, JG 
Rohwer, V Bittrich, eds. The families and genera of vascular plants. Vol 2. Springer, Berlin.

1993b Introduction to Centrospermae. Pages 13-19 in

K Kubitzki, JG Rohwer, V Bittrich, eds. The families and genera of vascular plants. Vol 2. Springer, Berlin.

Bittrich V, U Kühn 1993 Nyctaginaceae. Pages 473-486 in K Kubitzki, JG Rohwer, V Bittrich, eds. The families and genera of vascular plants. Vol 2. Springer, Berlin.

Cronquist A 1981 An integrated system of classification of flowering plants. Columbia University Press, New York. 1262 pp.

Cuénoud P, V Savolainen, LW Chatrou, M Powell, RJ Grayer, MW Chase 2002 Molecular phylogenetics of Caryophyllales based on nuclear $18 \mathrm{~S}$ rDNA and plastid rbcL, atpB, and matK DNA sequences. Am J Bot 89:132-144.

Davis G 1966 Systematic embryology of angiosperms. Wiley, New York. 528 pp.

Di Fulvio TE 1975 Estomatogénesis en Halophytum ameghinoi (Halophytaceae). Kurtziana 8:17-29.

Eckardt T 1976 Classical morphological features of centrospermous families. Plant Syst Evol 126:5-15.

Eliasson U 1988 Floral morphology and taxonomic relations among the genera of Amaranthaceae in the New World and Hawaiian islands. Bot J Linn Soc 96:235-283.

Erdtman G 1972 Pollen morphology and plant taxonomy: angiosperms. Hafner, New York. 553 pp.

Faegri K, L van der Pijl 1979 The principles of pollination ecology. Pergamon, Oxford. 244 pp.

Gibson AC 1978 Rayless secondary xylem of Halophytum. Bull Torrey Bot Club 105:39-44.

Holmgren PK, NH Holmgren, LC Barnett 1990 Index herbariorum. Pt I. The herbaria of the world. New York Botanical Garden, New York. 693 pp.

Hunziker JH, HD Behnke, IJ Eifert, TJ Mabry 1974 Halophytum ameghinoi: a betalain-containing and P-type sieve-tube plastid species. Taxon 23:537-539.

Hunziker JH, R Pozner, A Escobar 2000 Chromosome number in Halophytum ameghinoi (Halophytaceae). Plant Syst Evol 221: 125-127.
Hutchinson J 1959 The families of flowering plants. Vol 1. Oxford University Press, London. 510 pp.

Johri BM, KB Ambegaokar, PS Srivastava 1992 Comparative embryology of angiosperms. Springer, Berlin. $1221 \mathrm{pp}$.

Knuth P 1899 Handbuch der Blütenbiologie. Vol 2. Engelmann, Leipzig. 705 pp.

Kubitzki K 1993 Didieraceae. Pages 292-295 in K Kubitzki, JG Rohwer, V Bittrich, eds. The families and genera of vascular plants. Vol 2. Springer, Berlin.

Linder HP 1998 Morphology and evolution of wind pollination. Pages 123-135 in SJ Owens, PJ Rudall, eds. Reproductive biology in systematics, conservation and economic botany. Royal Botanic Gardens, Kew.

Nowicke JW, JJ Skvarla 1979 Pollen morphology: the potential influence in higher order systematics. Ann Mo Bot Gard 66:633-700.

Pozner R 2001 Approach to the early sporangial development in angiosperms considering meiosis control and cellular differentiation. Plant Syst Evol 230:25-42.

Ruzin SE 1999 Plant microtechnique and microscopy. Oxford University Press, New York. 322 pp.

Savolainen V, MW Chase, SB Hoot, CM Morton, DE Soltis, C Bayer, MM Fay, AY de Bruijn, S Sullivan, Y-L Qiu 2000 Phylogeny of the eudicots: a nearly complete familial analysis based on $\mathrm{rbcL}$ gene sequences. Kew Bull 55:257-309.

Skvarla JJ, JW Nowicke 1976 Ultrastructure of pollen exine in centrospermous families. Plant Syst Evol 126:55-78.

Soriano A 1946 Halophytaceae, nueva familia de Centrospermae. Notas Mus La Plata Bot 11:161-175.

— 1984 Halophytaceae. Bol Soc Argent Bot 23:161-162.

Spegazzini C 1899 Nova addenda ad floram patagonicam. An Soc Cient Argent 48:52.

1902 Nova addenda ad floram patagonicam. 3. An Mus Nac B Aires 7:135-308.

Takhtajan A 1959 Die Evolution der Angiospermen. Fischer, Jena. 344 pp. 1969 Flowering plants, origin and dispersal. Oliver \& Boyd, Edinburgh. 310 pp.

1997 Diversity and classification of flowering plants. Columbia University Press, New York. 643 pp. 


\section{Queries}

Q1 Nowicke 1996 is not listed in the literature cited. Please provide reference information.

Q2 For Spegazzini 1902, please verify that I provided the correct page numbers. 


\section{International Journal of Plant Sciences}

Dennis Keppeler

International Journal of Plant Sciences

1101 E. $57^{\text {th }}$ Street

Chicago, IL 60637

\section{Reprint Order Form}

Please return this form even if no reprints are ordered.

NO REPRINTS DESIRED

\section{PLEASE CHOOSE ONE OF THE FOLLOWING OPTIONS:}
$\square$ FREE COPIES OF JOURNAL ISSUE
$\square 1$ YEAR'S FREE SUBSCRIPTION OR RENEWAL

AUTHORS: REPRINT ORDER MUST BE RECEIVED PRIOR TO PRINTING OF JOURNAL ISSUE. Please return this form immediately even if no reprints are desired. Reprints ordered through an institution will not be processed without a purchase order number. Payment by check, Money Order, Visa, or MasterCard is required with all orders not accompanied by an institutional purchase order or purchase order number. Make checks and purchase orders payable to The University of Chicago Press.

\section{TO BE COMPLETED BY AUTHOR:}

International Journal of Plant Sciences

Vol No Month

Author(s): No of pages in article

Title of Article:

REPRINT CHARGES (please compute)

\begin{tabular}{ll}
\multicolumn{1}{c}{ Quantity } & $\$$ \\
\hline Covers & $\$$ \\
Subtotal & $\$$ \\
GST (7\% for Canadian destinations only) & $\$$ \\
Non-U.S. and non-Canada shipping & \\
(Non-U.S. orders add 45\% to subtotal) & $\$$ \\
TOTAL DUE (US \$) & $\$$
\end{tabular}

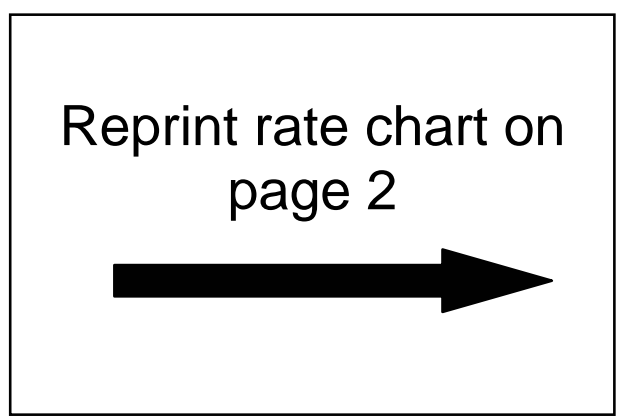

Prices include shipping for U.S. and Canadian orders. Non-U.S and non-Canadian orders are shipped via Airmail at an additional cost of $45 \%$ of the total printing charge.

\section{SHIPPING INSTRUCTIONS}

Name

Street

City State Zip

Country

\section{BILLING INSTRUCTIONS (Institutional Orders Only)} Institution

City __ State ___ Zip __
Country
*Phone

* Please include a phone number in case we need to contact you about your order

MAKE CHECKS AND PURCHASE ORDERS PAYABLE TO: The University of Chicago Press. All orders must be accompanied by one of the three payment options (purchase order, check/money order, or Visa/MasterCard):
1) $\square$ Check or Money Order for total charges is attached
OR
2) Please charge to:
VISA
MASTERCARD

Cardmember name as it appears on card (please print clearly)

Card Number Expiration Date

Signature Phone

3) Institutional Purchase Order No. 


\section{RETURN THIS REPRINT ORDER FORM WITH YOUR PROOFS TO:}

\section{International Journal of Plant Sciences}

Dennis Keppeler

International Journal of Plant Sciences

1101 E. $57^{\text {th }}$ Street

Chicago, IL 60637

DO NOT DELAY ORDERING YOUR REPRINTS: Orders must be in hand before the issue goes to press.

FORMAT: Offprints are printed exactly as articles appear in the journal, but without any backing material. They are trimmed on all sides and saddle-stitched. Covers are printed on white stock and include article title, author's name, copyright information, and issue date.

DELIVERY AND INVOICES: Reprints are shipped 2-4 weeks after publication of the Journal. Invoices are mailed at the time of shipment. For all orders charged to institutions, an official Purchase Order must be in hand before the reprint shipment can be released. Reprint orders payable by individuals must be accompanied by advance payment by check, Money Order, Visa, or MasterCard. In case of non-U.S. purchases, this payment must be made in the form of a check payable in U.S. currency via an American bank. Terms are net 30 days.

\section{REPRINT}

\section{PRICE LIST}

\section{Number of pages}

\begin{tabular}{|c|c|c|c|c|c|c|c|c|}
\hline & $1-4$ & $5-8$ & $9-12$ & $13-16$ & $17-20$ & $21-24$ & $\begin{array}{l}\text { add'l } 4 \\
\text { pages }\end{array}$ & $\begin{array}{c}\text { COVER } \\
\mathrm{S}\end{array}$ \\
\hline 25 & $\$ 26$ & $\$ 30$ & $\$ 35$ & $\$ 41$ & $\$ 46$ & $\$ 50$ & $\$ 6$ & $\$ 14.00$ \\
\hline 50 & $\$ 34$ & $\$ 40$ & $\$ 46$ & $\$ 53$ & $\$ 59$ & $\$ 66$ & $\$ 7$ & $\$ 18.00$ \\
\hline 100 & $\$ 52$ & $\$ 65$ & $\$ 77$ & $\$ 91$ & $\$ 103$ & $\$ 116$ & $\$ 13$ & $\$ 35.00$ \\
\hline 150 & $\$ 67$ & $\$ 86$ & $\$ 104$ & $\$ 125$ & $\$ 143$ & $\$ 163$ & $\$ 19$ & $\$ 53.00$ \\
\hline 200 & $\$ 87$ & $\$ 111$ & $\$ 135$ & $\$ 162$ & $\$ 174$ & $\$ 202$ & $\$ 25$ & $\$ 70.00$ \\
\hline 250 & $\$ 116$ & $\$ 147$ & $\$ 177$ & $\$ 211$ & $\$ 241$ & $\$ 276$ & $\$ 31$ & $\$ 88.00$ \\
\hline 300 & $\$ 138$ & $\$ 176$ & $\$ 212$ & $\$ 253$ & $\$ 289$ & $\$ 330$ & $\$ 37$ & $\$ 105.00$ \\
\hline 350 & $\$ 161$ & $\$ 204$ & $\$ 243$ & $\$ 294$ & $\$ 336$ & $\$ 373$ & $\$ 43$ & $\$ 123.00$ \\
\hline 400 & $\$ 183$ & $\$ 233$ & $\$ 329$ & $\$ 337$ & $\$ 385$ & $\$ 440$ & $\$ 49$ & $\$ 140.00$ \\
\hline
\end{tabular}

